\author{
Wojciech TERLIKOWSKI ${ }^{1}$ \\ Kacper WASILEWSKI ${ }^{2}$
}

\title{
EKSPOZYCJA ZABYTKOWYCH OBIEKTÓW ARCHITEKTURY ANTYCZNEJ NA PODSTAWIE WŁASNYCH PRZYKŁADÓW
}

\begin{abstract}
Celem artykułu jest analiza sposobów ekspozycji antycznych zabytkowych obiektów architektonicznych oraz odpowiadających im zabiegów konserwatorskich i restauratorskich. Na podstawie międzynarodowych traktatów, badań własnych oraz własnego doświadczenia w pracach konserwatorskich na wykopaliskach archeologicznych, autorzy dokonują opisu różnych sposobów prezentowania elementów dziedzictwa kulturowego jakim są antyczne zabytki. Wprowadzony zostaje podział antycznych obiektów ze względu na stan zachowania konstrukcji do czasów dzisiejszych, uwzględniający zarówno obiekty, które przetrwały w bardzo dobrej kondycji technicznej jak i obiekty, które nie przetrwały do dziś w formie innej niż opisy lub wizerunki oraz inne stany pośrednie. Przedstawione sposoby ekspozycji obiektów architektonicznych obejmują parki archeologiczne oraz inne formy prezentacji, między innymi rekonstrukcje rzeczywiste i rekonstrukcje wirtualne. Analiza działań konserwatorskich przedstawia działania charakterystyczne dla różnych stopni zachowania obiektów oraz różnych sposobów ich planowanej prezentacji. Została zobrazowana przykładami z doświadczenia autorów z wykopalisk prowadzonych na terenie Europy i Azji. W artykule zwrócono szczególną uwagę na potrzebę interdyscyplinarnych badań obejmujących nie tylko konserwowany obiekt, ale i jego otoczenie oraz podobne obiekty o zbliżonej technologii i technice wykonania. Takie badania są niezbędne w celu zachowania odpowiedniego poziomu autentyczności i wiarygodności historycznej podczas prac konserwatorskich i restauratorskich. Wskazano także wpływ jaki ma poprawnie przeprowadzona konserwacja i odpowiednio przygotowana ekspozycja zabytkowych obiektów architektonicznych na rozwój gospodarki lokalnej oraz na realizację zasad zrównoważonego rozwoju.
\end{abstract}

Słowa kluczowe: parki archeologiczne, trwała ruina, międzynarodowe traktaty o zachowaniu dziedzictwa kulturowego, zasady zrównoważonego rozwoju

\footnotetext{
${ }^{1}$ Autor do korespondencji: dr inż., Politechnika Warszawska, Wydział Inżynierii Lądowej, Instytut Inżynierii Budowlanej, w.terlikowski@il.pw.edu.pl

${ }^{2}$ mgr inż., Politechnika Warszawska, Wydział Inżynierii Lądowej, Instytut Inżynierii Budowlanej, k.wasilewski@il.pw.edu.pl
} 


\section{Wstęp}

Międzynarodowa Karta Ochrony i Zarządzania Dziedzictwem Archeologicznym (Karta Lozańska) wskazuje na istotne znaczenie prezentacji dziedzictwa archeologicznego, czyli także zabytków architektury antycznej, w zrozumieniu genezy i rozwoju współczesnych społeczeństw oraz podkreśla duży wpływ ekspozycji zabytków na świadomość o potrzebie ochrony tego dziedzictwa [1]. W 1992 r. sporządzona została Europejska konwencja o ochronie dziedzictwa archeologicznego [2]. Przypomina ona, że dziedzictwo archeologiczne ma zasadnicze znaczenie dla wiedzy o historii ludzkości. Ochrona jego, a także rzetelne badania są zadaniem wszystkich, którzy odpowiadają za prawdę naukową. Żyjący współcześnie mają ten obowiązek do spełnienia wobec przyszłych pokoleń. Jest to ściśle związane z szerszym aspektem spraw społecznych, gospodarczych, edukacyjnych, wynikających z powszechnie uznawanych zasad zrównoważonego rozwoju. Ostanie dekady potwierdziły, że europejskie dziedzictwo archeologiczne, stanowiące dowód najstarszej historii, dotyczące często wymarłych cywilizacji, jest poważnie zagrożone zniszczeniem. W myśl konwencji [2] przedmiotem dziedzictwa archeologicznego są wszelkie pozostałości, obiekty i jakiekolwiek inne ślady ludzkości z minionych epok, których zachowanie i analiza pomogą prześledzić historię ludzkości i jej stosunek do środowiska naturalnego. Są to również obiekty, dla których wykopaliska i odkrycia oraz inne metody badań nad dziejami ludzkości i jej środowiskiem są podstawowym źródłem informacji. Wśród najistotniejszych śladów dawnych epok i cywilizacji są zabytki architektury i budownictwa, świadczące o rozwoju technologicznym ich autorów, poziomie życia mieszkańców, kanonach estetycznych, które obowiązywały w minionych epokach. Dziedzictwo archeologiczne obejmuje struktury, konstrukcje, zespoły budowlane, a także ich otoczenie, układy urbanistyczne. Ze względu na ciągłość sztuki budowlanej wiedza o budownictwie, układach architektonicznokonstrukcyjnych, formach, stosowanych technologiach, rozwiązaniach materiałowych i technicznych może również duże znaczenie dla współczesności. Na mocy konwencji [2] jej sygnatariusze zostali zobowiązani do utworzenia systemu prawnego do ochrony dziedzictwa archeologicznego, a w szczególności do utworzenie archeologicznych rezerwatów - parków, w których należy eksponować uratowane dla przyszłych pokoleń zabytki architektury i budownictwa, nawet jeżeli pozostają po nich tylko niewielkie ślady. Będą one również możliwością pozostawioną przyszłym pokoleniom, jako źródło analiz. Aby zachować dziedzictwo archeologiczne, będące częścią dziedzictwa kulturowego, a także rzetelność badań obiektów i obszarów je tworzących, konwencja [2] nakazuje stosowanie następujących zasad: zapewnienie odpowiedniej kontroli i nadzoru nad wykopaliskami i pracami archeologicznymi oraz konserwatorskimi; stosowanie metod badawczych nieniszczących i nie fałszujących historycznej oryginalność (szczególnie ważne jest to zalecenie do stosowania w pracach konserwatorskich, zabezpieczających, wzmacniających, poprawiających trwałość konstrukcji budowlanych); odpowiednie zabezpieczenie po zbadaniu wszystkich odkrytych artefaktów 
(w skrajnym przypadku, gdy jest to nie możliwe z różnych przyczyn, zaleca się ponowne ich zasypanie, aby umożliwić badania w przyszłości); właściwą konserwację wszystkich obiektów archeologicznych, a szczególnie architektury i budownictwa, które najczęściej pozostają w stanie trwałej ruiny i są narażone na różne oddziaływania destrukcyjne. Należy tu zaznaczyć, że najlepszym rozwiązaniem dla wszystkich zabytków archeologicznych, a szczególnie dla obiektów architektoniczno-budowlanych, jest właściwa ich konserwacja i pozostawienie na miejscu. Ekspozycja ,in situ”, z właściwym kontekstem obszarowym, historycznym, geograficznym ukazuje pełną prawdę o obiekcie zabytkowym i jest o wiele pełniejsza formą edukacji i promocji zabytków. Wszystkie te zalecenia implikują konieczność wielu interdyscyplinarnych działań, w tym inżynierskich, do których można zaliczyć właściwą analizę, a często również konieczne zmiany, planów zagospodarowania przestrzennego obszarów, na których znajdują się lub mogą się znajdować archeologiczne obiekty zabytkowe architektury i budownictwa oraz doskonalenie i realizowanie właściwej metodologii $\mathrm{w}$ pracach konserwatorskich, budowlano-inżynierskich i technicznych przy tych zabytkach.

\subsection{Stan zachowania zabytków architektury antycznej}

Jedną z największych trudności związanych z zabezpieczeniem i konserwacją antycznych obiektów architektonicznych jest zły stan techniczny, w jakim zachowały się do czasów współczesnych. Wynika to bezpośrednio z czasu jaki upłynął od momentu ich powstania i użytkowania do dziś. Przez ok. 20 wieków, jakie dzielą nas od starożytności, konstrukcje te były poddane działaniom zarówno środowiskowym, takim jak deszcze, niskie temperatury czy trzęsienia ziemi i powodzie, jak i działalności człowieka, która mogła mieć zarówno pozytywny wpływ na utrzymanie stanu technicznego - np. remonty, adaptacje, jak i destrukcyjny - np. wyburzenia czy działania wojenne. Istotną cechą, która sprawia, że część obiektów budowlanych przetrwała długi okres czasu w dobrym stanie technicznych jest trwałość materiałów, elementów, układów i ustrojów konstrukcyjnych. Trwałość obiektów budowlanych zależy od wielu czynników - od rodzajów i jakości materiałów, z których zostały one wykonane, przyjętych technologii budowlanych i rozwiązań technicznych, układów konstrukcyjnych, ekspozycji w terenie, kwalifikacji budowniczych i wynikających z tego jakości zrealizowanych robót budowlanych, odporności na zmiany środowiskowe zachodzące na przestrzeni historii (np. podniesienie lub obniżenie poziomu wód gruntowych, zmiany klimatyczne), odporność na zmiany cywilizacyjne (np. powstanie autostrad w bezpośredniej bliskości zabytków, powodujących drgania). Bardzo dobrym przykładem różnej trwałości konstrukcji budowlanych wykonanych w starożytności w rożnych technologiach są bazyliki wczesnochrześcijańskie w Palmyrze (Syria) [3]. Konstrukcja bazylik jest murowana z kamienia wapiennego, lecz wykonana w dwóch technologiach rzymskich - tzw. „opus palmyrenum” ściana warstwowa i „opus quadratum”- $\mathrm{z}$ ciosów kamiennych. „Opus palmyrenum” był murem warstwowym, tworzonym z prostopadłościennych, płaskich płyt kamiennych. Mają one zbliżony ciężar do ciosów kamiennych, jednak ze względu 
na mniejszą grubość, mają większą powierzchnię boczną. Powierzchnie boczne nadawały się więc bardzo dobrze na elewacje ścian. Elementy te montowane były w murze równolegle, parami, tworząc wewnętrzną i zewnętrzną powierzchnię ściany. Stanowiły one właściwą konstrukcję nośną ściany, przenoszącą obciążenia pionowe. Kolejną oszczędnością $\mathrm{w}$ tej technologii, było wypełnienie przestrzeni między płytami gruzem, wymieszanym z zaprawą wapienną, którą wypełnione były również spoiny między płytami. Elementem usztywniającym mur w płaszczyznach poziomych były oczepy, wykonane z płaskich, prostopadłościennych płyt (sięgaczy), szerokości muru. Mury z klasycznych ciosów kamiennych okazały się trwalsze, jednak w Palmyrze nie zachowały się również w całości. Wynika to z tego, że bloki kamienne, posiadające trwałą strukturę, tworzące mury ciosowe mogły być łatwo rozebrane, a elementy je tworzące powtórnie użyte w innych budynkach lub budowlach. Chociaż mur wykonany w technologii „opus palmyrenum” był bardziej ekonomiczny dla inwestorów i budowniczych, okazał się murem relatywnie nietrwałym [3].

Ze względu na stan techniczny, antyczne zabytki architektury można podzielić na kilka grup. Pierwszą, spotykaną niezwykle rzadko, stanowią zabytki niewymagającej (bądź wymagające w bardzo ograniczonym zakresie) interwencji konserwatorskiej. Tego typu obiekty charakteryzują się brakiem istotnych ubytków w elementach konstrukcyjnych oraz brakiem zniszczeń w strukturze materiału, z którego zostały wykonane. Tak dobry stan zachowania konstrukcji wymagał szczególnych warunków zarówno środowiskowych - łagodny, z punktu widzenia

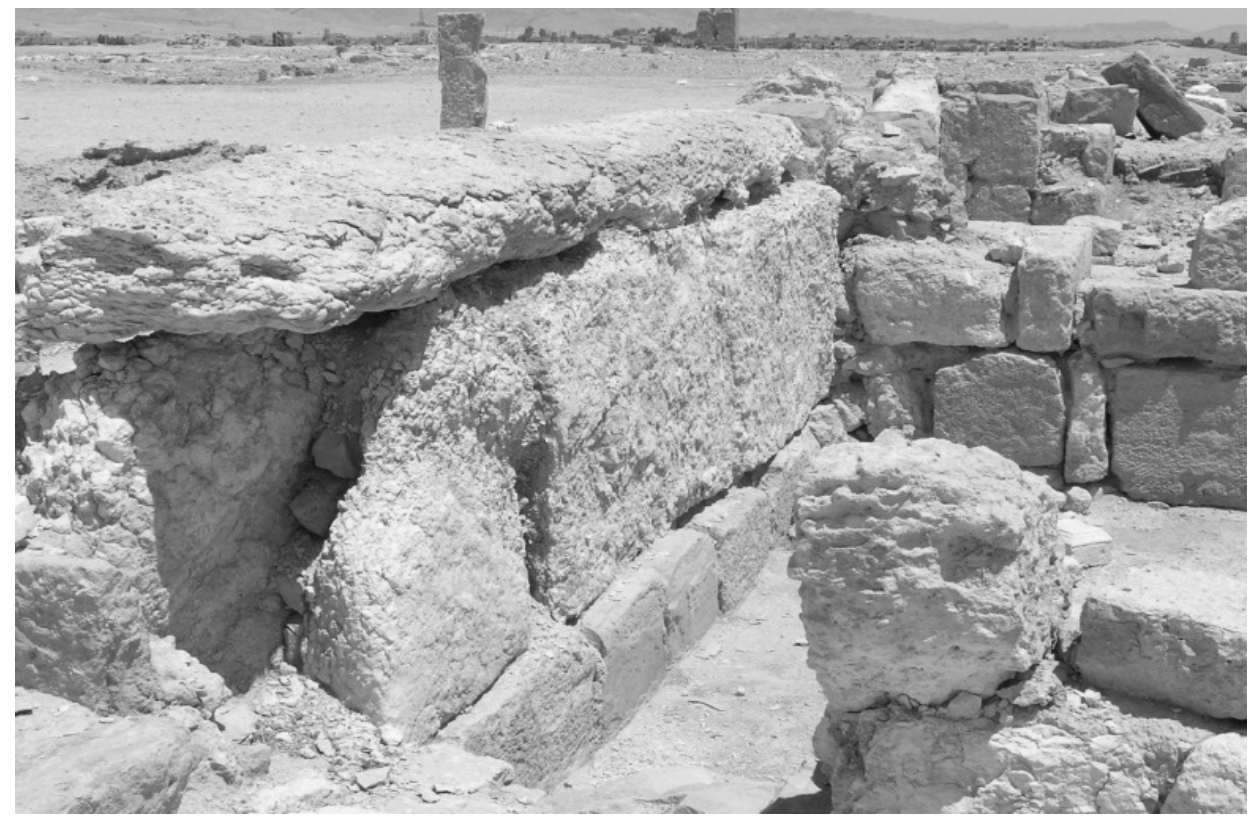

Rys. 1. Opus palmyrenum

Fig. 1. Opus palmyrenum 
konstrukcji klimat, jak i odpowiedniego materiału - w zasadzie jedynymi konstrukcjami, które w odpowiednich warunkach mogły przetrwać do czasów dzisiejszych bez zniszczeń $\mathrm{w}$ strukturze materiału, są konstrukcje kamienne. W celu przygotowania tego typu obiektów do ekspozycji wymagane są jedynie prace adaptacyjne, takiej jak przygotowanie tablic informacyjnych czy opracowanie tras zwiedzania. Obiekty takie są zazwyczaj współcześnie użytkowane lub eksponowane, a ich stan techniczny jest stale kontrolowany i w razie konieczności poddawane są bieżącej konserwacji. Przykładem tego typu konstrukcji są piramidy w Gizie.

Drugą grupę stanowią obiekty budowlane o zachowanej strukturze, która jednak nie spełnia wymagań bezpieczeństwa konstrukcji i użytkowania [4]. Obiekty takie nie mogą zostać udostępnione do zwiedzania bez odpowiednich działań konserwatorskich i zabezpieczających konstrukcję. Istotnym zagadnieniem jest tutaj ograniczenie lub zatrzymanie destrukcji strukturalnej obiektu zabytkowego. Tego typu obiekty wymagają zazwyczaj ingerencji w strukturę istniejącą, poprzez działania inżynierskie naprawcze, wzmacniające i poprawiające trwałość obiektu. Oryginalna bryła takiego obiektu jest zachowana, co w znacznym stopniu umożliwia zachowanie autentycznego kształtu i charakteru obiektu (np. świątynia Hatszepsut w Egipcie, Koloseum w Rzymie).

Kolejną grupą są obiekty, które przetrwały do czasów dzisiejszych jedynie w formie ruiny. Na podstawie analizy pozostałości oraz innych źródeł możliwe jest odtworzenie oryginalnej bryły zabytku oraz ustalenie jego charakteru i funkcji. Ustroje konstrukcyjne takich obiektów zabytkowych i elementy je tworzące przetrwały najczęściej jedynie we fragmentarycznej formie albo uległy całkowitemu zniszczeniu. Ich odtworzenie wymaga szczegółowych badań $i$ analiz. Istotnym elementem takich badań powinna być analiza technologii i techniki wznoszenia oryginalnych konstrukcji oraz materiałów z których zostały wykonane. Umożliwi to zachowanie wiarygodności historycznej oraz autentyczności konstrukcji w dalszych pracach konserwatorsko-inżynierskich. Bardzo często struktura materiału, z którego wykonano badane konstrukcje ulega zniszczeniu - dezintegracji granularnej, a jej wzmocnienie stanowi istotny problem konstrukcyjno-konserwatorski.

Ostatnią, czwartą, grupę stanowią obiekty, które nie przetrwały do czasów dzisiejszych. Informacje na ich temat można czerpać z ewentualnych pozostałych fragmentów detali architektonicznych oraz badań porównawczych, ikonograficznych, historycznych ( $\mathrm{z}$ opisów i wizerunków zawartych w literaturze, na obrazach, rzeźbach czy monetach.[5]). Dzięki analizie materiałów źródłowych, uwzględniając badania dotyczące technologi i techniki wykonywania konkretnych obiektów, możliwe jest wykonanie rekonstrukcji takich zabytków. Istną kwestią, przy tego typu zabiegach, jest zachowanie wiarygodności i autentyczności konstrukcji, w związku z tym badania muszą być szczegółowe i obejmować wszystki możliwe źródła. 


\subsection{Sposoby prezentacji antycznych obiektów architektury}

Podstawowym kryterium podziału sposobów ekspozycji zabytkowych obiektów architektury, jaki można wprowadzić, jest podział z uwagi na lokalizację obiektu względem orignalnego położenia. Obiekty znajdujące się w sowojej autentycznej lokazlizacji najczęściej prezentowane są w formie parków archologicznych, gdzie mogą znajdować się obiekty zarówno w stanie trwałej ruiny, jak $\mathrm{i}$ w formie zrekonstruaowanej. W przypadku prowadzania prac restauratorskich istotne jest przeprowadznie ich w sposób zgodny z przepisami przyjętymi w traktatach międzynarodowych (Karta Ateńska, Karta Wenecka) [6], a w szczególności w taki sospób aby wszystkie rekonstruowane fragmenty były możliwe do odróżnienia od fragmentów oryginalnych stanowiących świadectwo archeologiczne. Szczgólnie wartościową formą prezentacji obiektów architektonicznych jest zachowanie ich w stanie trwałej ruiny w miejscu, w którym zachowały się do czasów współczesnych, w całym kontekście otoczenia, ekspozycji, warunków naturalnych i geograficznych. Ekspozycja tych zabytków w połączeniu z wizualizacją, rekonstrukcją wirtualną mogącą odzwierciedlać fazy rozwoju budynku i otoczenia, a także fazy destrukcji jest szczególnie ważna i posiada wielkie walory edukacyjne. Może to być zrealizowane na przykład na tablicach informacyjnych, znajdujących się w pobliżu zabytku. Umożliwa to ukazanie obiektu w pierwotnej formie bez naruszania stanowiska archeologiczengo. Parki archologiczne mogą stanowić zarówno samodziele obiekty, zlokalizowane w miastach lub poza, jak i mogą być wpisane w tkankę miejską. Najcześciej parki pierwszego typu obejmują swoim obszarem konkretny kompleks, w którego skład wchodzą obiekty architektoniczne o różnym charakterze.Przykładem tego typu obiektu jest park archologiczny na terenie Chersonezu Taurydzkiego w Sewastopolu (Rys. 2). Parki wpisane w zabudowę miejską często prezentują jeden lub kilka obiektów pierwotnie zlokalizowanych w obrębach dzisiejszego miasta, które ze względu na duże znaczenie historyczne lub estetyczne zostały zachowane i przygotowane do ekspozycji tej formie. Istotnym zagadnieniem inżynierskim, w przypad$\mathrm{ku}$ takiej formy prezentacji, jest połączenie substancji zabytkowej $\mathrm{z}$ formami współczesnymi, np. bazylikami, kościołami. Przykładem integracji współczesnej zabudowy z obiektem będącym świadectwem archeologicznym jest nowożytna bazylika zbudowana przy Grocie Zwiastowania w Nazarecie (Rys. 3).

Rekonstrukcje zabytków architektury antycznej w lokalizacjach innych niż pierwotne powinny być wykonane w oparciu o odpowiednie badania oraz opatrzone informacją o ich oryginalnej lokalizacji. Często spotykaną praktyką są rekonstrukcje wykonywana na potrzeby muzealne.

Odzielną formą prezentacji, głównie objemującą fragmenty konstrukcji i detali architektonicznych zabytków antycznych są ekspozycje muzealne. W takich przypadkach także istonte jest wskazanie miejsca pochodzenia fragmentu. Dużą wartość edukacyjną mają rekonstrukcje, na przykład w formie rysunkowej, ukazujące orginalne umiejscowienie detali $\mathrm{w}$ prawdopodobnej bryle całego budynku. Usytuowanie fragmentu konstrukcji bez kontekstu całego budynku lub budowli, może całkowicie wypaczyć obraz ekspozycji. 


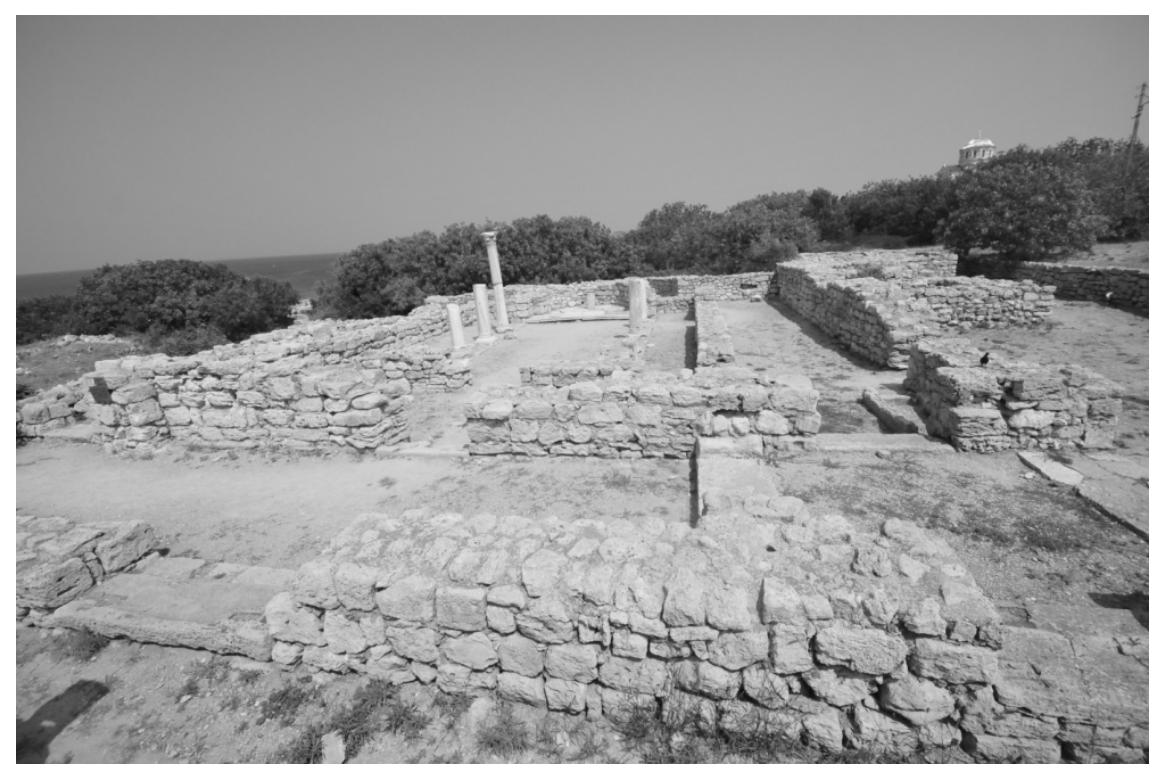

Rys. 2. Chersonez Taurydzki - rezerwat archeologiczny

Fig. 2. Chersoneses - archaeological park

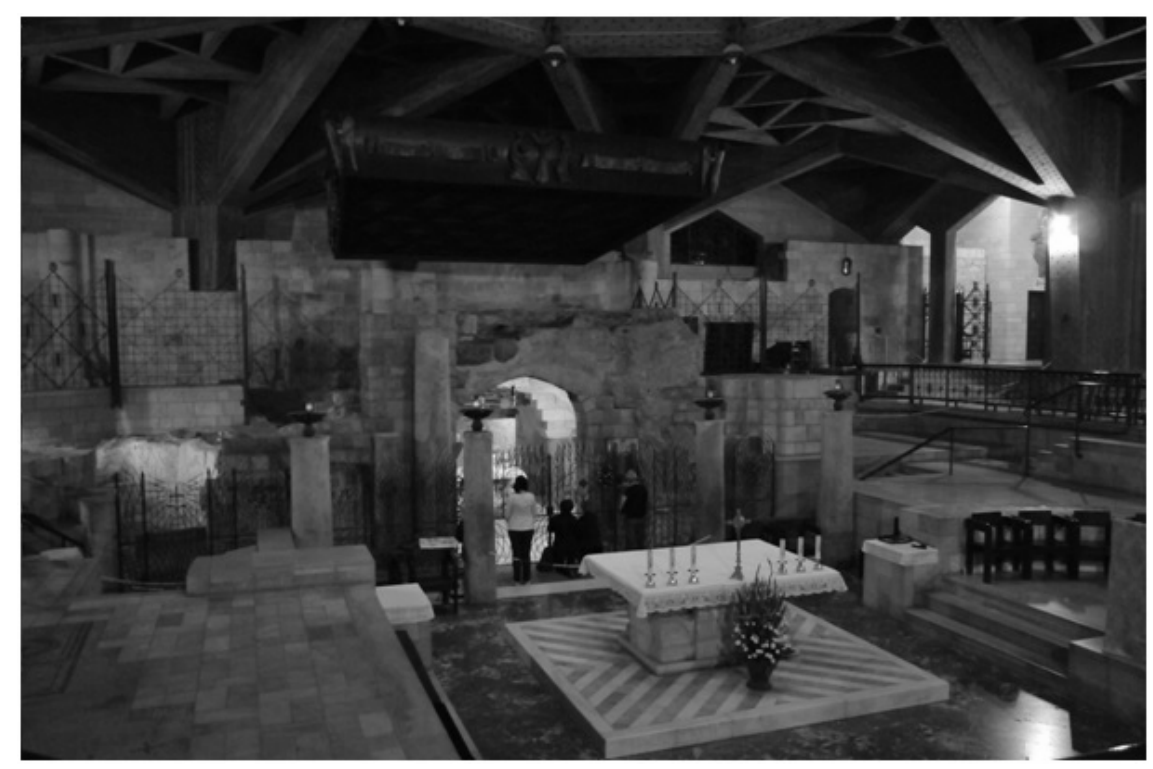

Rys. 3. Współczesna bazylika wybudowana w miejscu wykopalisk, przy Grocie Zwiastowania w Nazarecie

Fig. 3. Modern basilica built in the excavation site, the Grotto of the Annunciation in Nazareth 


\section{Zabezpieczenie obiektów architektonicznych - zagadnienia ogólne}

W zależności od planowanego sposobu ekspozycji, konserwacja i zabezpieczenie antycznych obiektów architektonicznych charakteryzują się różnymi trudnościami. Wspólnym problemem, jaki z reguły pojawia się $\mathrm{w}$ przypadku pracy z obiektami antycznymi, jest brak dokładnych danych dotyczących obiektów, ich funkcji i kształtu. Dodatkowo, w związku ze znacznym wiekiem konstrukcji, zachowały się one często fragmentarycznie i charakteryzują się znacznym stopniem zniszczenia. Tego typu trudności wymuszają przeprowadzenie odpowiednich badań historycznych, włączając w to badania ikonograficzne i porównawcze, w celu dobrania odpowiednich technik i technologii konserwatorskich. Szczególną trudnością, która wynika z często ograniczonych źródeł informacji o obiekcie, jest zachowanie prawdy historycznej i autentyczności konstrukcji.

Zabezpieczenia konstrukcji architektonicznych można podzielić na zabezpieczenia mające na celu wzmocnienie bądź odbudowę konstrukcji nośnej obiektu oraz na działania związane z poprawą trwałości obiektu - na przykład poprawą odporności na oddziaływania atmosferyczne. Zapewnienie bezpieczeństwa konstrukcji oraz ewentualnie możliwość jej użytkowania związana jest z formą późniejszej ekspozycji i stanowi istotne wyzwanie inżynierskie.

Charakterystycznym dla obiektów architektury antycznej jest zabezpieczanie ich w stanie trwałej ruiny, w którym przetrwały do czasów dzisiejszych. Zagadnienie to jest szczególnie istotne w przypadku konstrukcji odsłoniętych w ramach wykopalisk archeologicznych. Tego typu zabytki bardzo często nie spełniają wymogów bezpieczeństwa konstrukcji i wymagają gruntownego wzmocnienia oraz zabezpieczenia przed destrukcyjnymi czynnikami środowiskowymi, na które nie były narażone wcześniej ponieważ znajdowały się pod ziemią. W przypadku konstrukcji murowych częstym zabiegiem jest konsolidacja i reprofilacja. Jeden ze sposobów jej przeprowadzania polega na wzmocnieniu wewnętrznej struktury muru przez iniekcje zaprawą naprawczą, a następnie przemurowanie górnej warstwy muru. Tego typu zabieg zapewnia wewnętrzną spójność muru oraz zabezpiecza przed penetracją wody w głąb muru, co jest istotnym zagadnieniem w przypadku obiektów docelowo znajdujących się na wolnym powietrzu jako fragment ekspozycji parku archeologicznego. Wszystkie zrekonstruowane elementy muszą w wyraźny sposób odróżniać się od autentycznej konstrukcji. Przykładem starożytnych konstrukcji, znajdujących się w stanie trwałej ruiny, tworzących rezerwat archeologiczny oraz zabiegów konserwatorskich, jakim są one poddawane, jest stanowisko archeologiczne Tyritake w miejscowości Kercz, Ukraina (Rys. 4). Misja konserwatorska Wydziału Inżynierii Lądowej Politechniki Warszawskiej, pracująca w tym miejscu od 2011 roku, uczestniczy w międzynarodowym projekcie badawczym" Zabytki Bosporu Kimmeryjskiego" [7]. Specyfiką badanych i konserwowanych konstrukcji murowych jest tutaj różnorodność form i technik konstrukcyjnych wynikających z dużego rozkładu datowania 


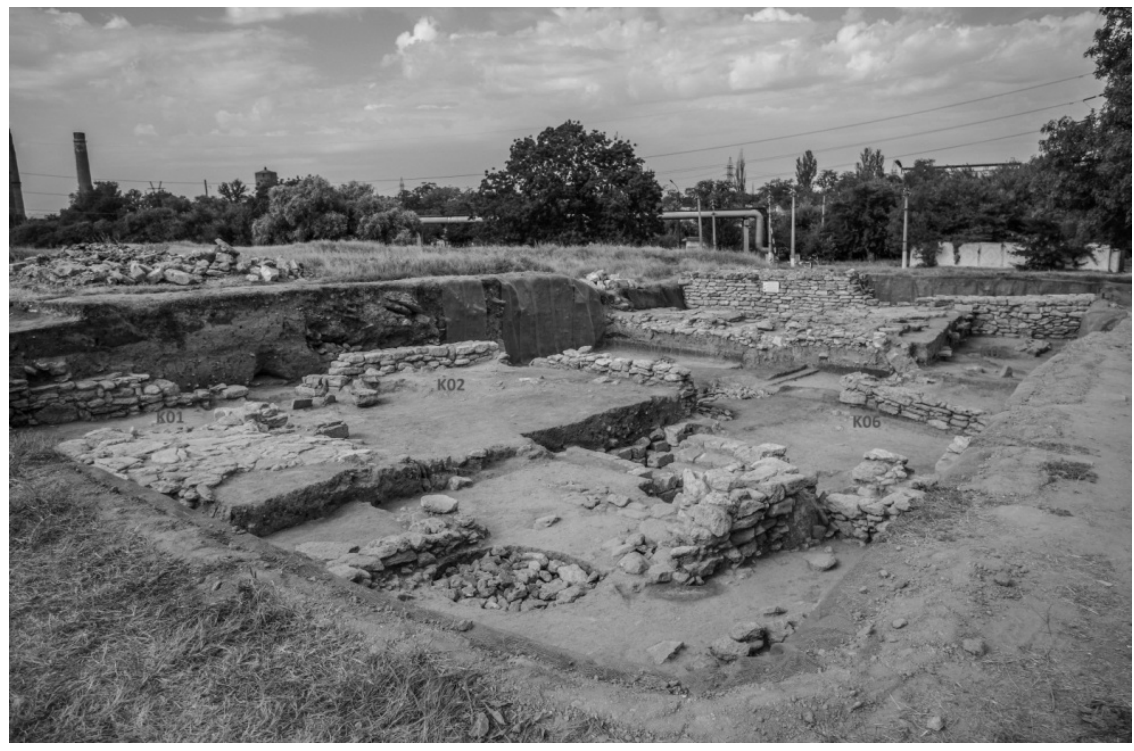

Rys. 4 Wykopaliska na terenie antycznego miasta Tyritake w Kerczu, Ukraina

Fig. 4 The archeologically site in ancient city Tyritake, Kerch, Ukraine

ich powstania - od $\mathrm{V}$ wieku p.n.e. do $\mathrm{V}$ wieku n.e. $\mathrm{W}$ pracach konserwatorskich należało również uwzględnić lokalne uwarunkowania (społeczne i ekonomiczne), w tym dostępność materiałów konserwatorskich. Podstawowymi zagadnieniami i problemami rozwiązanymi w czasie badań były: opracowanie kompleksowego programu konserwatorskiego, dostosowanego do lokalnych oczekiwań oraz do wymagań międzynarodowych traktatów dotyczących konserwacji zabytków i obiektów archeologicznych; właściwa diagnostyka stanu technicznego konstrukcji murowych, uwzględniająca określenie parametrów fizycznych i wytrzymałościowych elementów murowych i zaprawy oraz technik i technologii stosowanych w czasie wznoszenia konstrukcji (w oparciu o nie prowadzone były wszystkie prace konserwatorskie); określenie przyczyn destrukcji konstrukcji i materiałów oraz sposobów jej zatrzymania; określenie zasad wzmocnienia muru -zaprawy i elementów murowych oraz konsolidacji muru; określenie materiałów możliwych do użycia w pracach konserwatorskich z uwzględnieniem lokalnych ograniczeń; zabezpieczenie konstrukcji przed destrukcyjnymi oddziaływaniami środowiska naturalnego (opady atmosferyczne oraz zmienne temperatury, destrukcyjna działalność ujemnych temperatur); hydrofobizacja konstrukcji; wybór i zastosowanie odpowiednich, tymczasowych i trwałych, zabezpieczeń terenu wykopalisk przed wpływem warunków atmosferycznych i zagrożeń społecznych (związanych $\mathrm{z}$ ingerencją osób postronnych). Prace konserwatorskie $\mathrm{i}$ inżynierskie polegały przede wszystkich na wzmocnieniu istniejących fragmentów murów. Ze względu na bardzo zły stan techniczny ruin (mury dzikie na zaprawie glinianej, popękane, rozwarstwione wewnętrznie i zewnętrznie, materiały 
zdezintegrowane granularnie) wykonano konsolidacje murów oraz miejscowe reprofilacje i nadbudowy metodą anastylozy. Warstwy nadbudowywane oddzielone zostały od warstw pierwotnych warstwami ceramiki. Reprofilację murów przeprowadzono etapami: przemurowanie, spojenie, konsolidacja zaprawą gliniano-cementową; spoinowanie - nakładanie zaprawy glinianej w spoinach na mokrą zaprawę; uzupełnienie spoin zaprawą glinianą po stwardnieniu zaprawy murarskiej; oczyszczenie mechaniczne muru; naprawa i wzmocnienie spoin oraz scalenie kolorystyczne. Ostatnim etapem prac była hydrofobizacja muru [7].

Wszystkie rodzaje robót konserwatorskich i inżynierskich, wykonywane in situ oraz na potrzeby wystaw muzealnych, muszą być poprzedzone odpowiedni$\mathrm{mi}$, rzetelnymi, interdyscyplinarnym i wieloaspektowymi badaniami. Przeprowadzenie takich badań oraz stworzenie na ich podstawie odpowiedniej dokumentacji ma na celu zapewnienie autentyczności rekonstruowanego obiektu. Jednym ze sposobów rekonstrukcji obiektów architektonicznych jest anastyloza. Jest to zabieg polegający na ponownym ustawieniu obiektu, który uległ zawaleniu lub rozbiciu. Dużym utrudnieniem jest sytuacja gdy obiekt jest niekompletny i zachodzi potrzeba wykonania uzupełnień. Uzupełnienia te, z punktu widzenia konserwatorskiego, powinny być wyraźnie różne od elementów prawdziwych, jednak z punktu widzenia artystyczno-architektonicznego powinny być jak najmniej zauważalne. Materiał z jakiego wykonywane są brakujące elementy może być taki sam jak wykorzystany w obiekcie lub taki aby w sposób kontrastowy ukazywać uzupełnienia. Przykładem anastylozy jest ponowne ustawienie kolumn w portyku bazyliki wczesnochrześcijańskiej w Palmyrze (Syria) (Rys. 5).

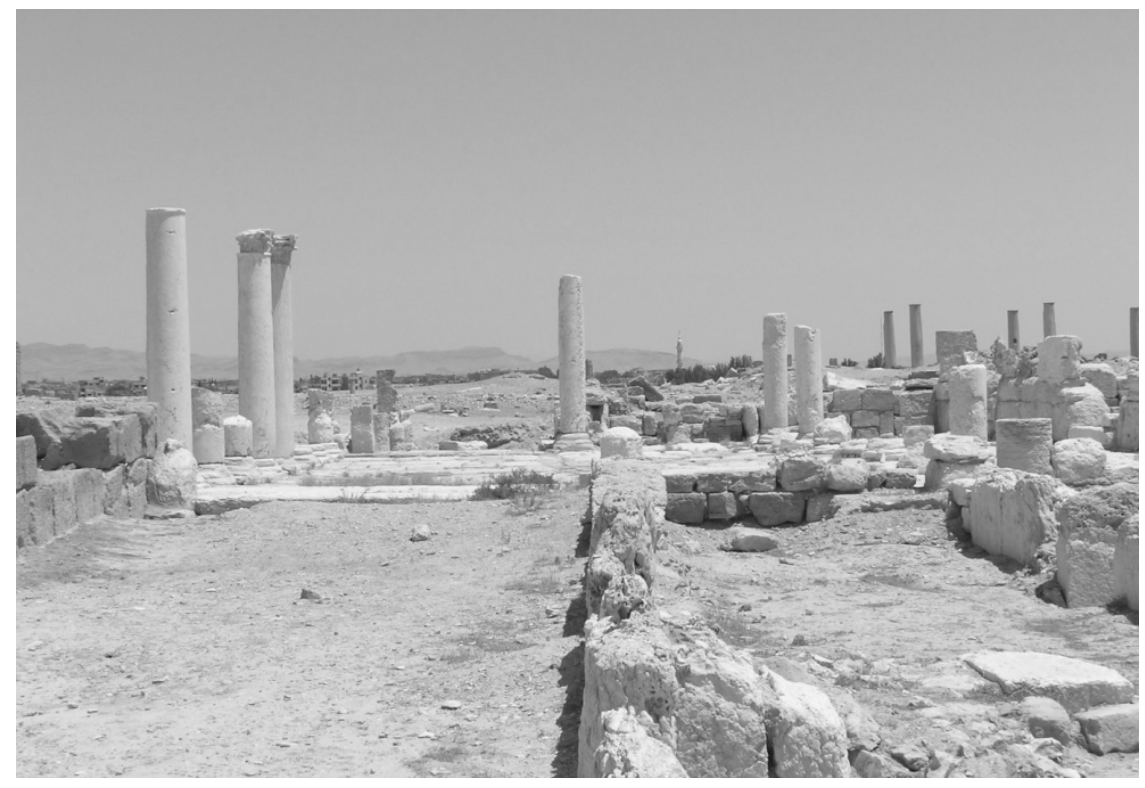

Rys. 5 Przykład anastylozy - wczesnochrześcijańska bazylika w Palmyrze (Syria)

Fig. 5 The anastylosis example - Early Christian basilica in Palmyra (Syria) 
Przeprowadzenie szczegółowych badań i odpowiednia ich dokumentacja jest szczególnie istotna przy rekonstrukcjach wirtualnych. Wynika to z potrzeby zapewnienia odpowiedniej wiarygodności historycznej oraz spójności merytorycznej efektów wizualizacji, a co za tym idzie traktowanie ich na równi z tradycyjnymi metodami badań i formami prezentacji. Karta Londyńska wprowadza zasady stosowania metod wizualizacji komputerowych jako badań naukowych i w celu popularyzacji wiedzy o dziedzictwie kulturowym. Istotnym założeniem jest każdorazowa ocena stopnia wiarygodności wizualizacji oraz jednoznaczne określenie czy wizualizacja oddaje stan istniejący, odtwarza fazę historyczną, czy też jest domniemaną rekonstrukcją badanego obiektu [8].

\section{Wnioski}

Konserwacja zabytków architektury antycznej jest zadaniem wymagającym dużej wiedzy i doświadczenia. W celu przeprowadzenia jej w sposób poprawny, zgodny z wymogami międzynarodowych traktatów, wymagane są dokładne badania o interdyscyplinarnym charakterze, obejmujące zarówno konserwowany obiekt jak i jego otoczenie oraz inne obiekty o zbliżonym charakterze. Dopiero tak szerokie badania pozwalają na uzyskanie zadawalającego poziomu autentyzmu i wiarygodności historycznej, które decydują o walorach edukacyjnych zrewitalizowanego zabytku. Odpowiednio dobrana i przygotowana forma ekspozycji antycznych obiektów zabytkowych, będących elementami dziedzictwa kulturowego, mogą w znaczącym stopniu wpłynąc na turystyczne walory regionu, przyczyniając się do rozwoju gospodarki w obszarze turystyki. Właściwa konserwacja konstrukcji antycznych, w połączeniu z poprawą ich trwałości i wzmocnieniem, w rezerwatach archeologicznych i poza nimi, jest właściwą realizacją zadania ochrony dziedzictwa kulturowego. Właściwe eksponowanie antycznych zabytków architektury i budownictwa ma olbrzymie walory edukacyjne. Powyższe działania zabezpieczające obiekty zabytkowe przed zniszczeniem i zachowujące dla przyszłych pokoleń, są najwłaściwszą realizacją zasad zrównoważonego rozwoju.

\section{Literatura}

[1] Międzynarodowa Karta Ochrony i Zarządzania Dziedzictwem Archeologicznym, Lozanna 1990.

[2] Europejska konwencja o ochronie dziedzictwa archeologicznego (poprawiona), sporządzona w La Valetta dnia 16 stycznia 1992 r., Dziennik Ustaw1996 r., Nr 120, poz. 564.

[3] Terlikowski W.: The Specificity of Research, Conservation and Reconstruction of Real and Virtual Early Christian Basilicas in Palmyra, Syria. PROHITECH'14, 7-9 May 2014, Antalya-Turkey, Proceedings of the $2^{\text {nd }}$ International Conference on Protection of Historical Constructions, Editors Federico M. Mazzolani, Gulay Altay, Bogazici University Publishing 34342 Beebek, Istanbul Turkey, ISBN NUMER: 978-975-518-3619, PUBLISHING NUMBER:1103, p.699-705.

[4] Rozporządzenie Ministra Infrastruktury z 12 kwietnia 2002r w sprawie warunków technicznych, jakim powinny odpowiadać budynki i ich usytuowanie. Dz. U. 2002 r., $\mathrm{Nr} 75$ z późniejszymi zmianami. 
[5] Marecki A., Wasilewski K.: A Virtual Reconstruction of an Unknown Roman Bridge from the $1^{\text {st }}$ Century A.D. PROHITECH'14, 7-9 May 2014, Antalya-Turkey, Proceedings of the $2^{\text {nd }}$ International Conference on Protection of Historical Constructions, Editors Federico M. Mazzolani, Gulay Altay, Bogazici University Publishing 34342 Beebek, Istanbul Turkey, ISBN NUMER: 978-975-518-361-9, PUBLISHING NUMBER:1103, p.707-712.

[6] Międzynarodowa Karta Konserwacji i Restauracji Zabytków i Miejsc Zabytkowych, Wenecja 1964.

[7] Terlikowski W., Wasilewski K.: Technical problems for maintenance and preservation of ancient masonry structures from the point of view of the exposition in archaeological parks for example the excavation in Tyritake in Kerch (Ukraine), PROHITECH'14, 7-9 May 2014, Antalya-Turkey, Proceedings of the $2^{\text {nd }}$ International Conference on Protection of Historical Constructions, Editors Federico M. Mazzolani, Gulay Altay, Bogazici University Publishing 34342 Beebek, Istanbul Turkey, ISBN NUMER: 978-975-518361-9, PUBLISHING NUMBER:1103, p.759-765.

[8] The London Charter for the Computer-based Visualisation of Cultural Heritage, pod red. Hugh Denard, King's College London, 7 lutego 2009.

\section{THE ANCIENT ARCHITECTURAL MONUMENTS EXPOSITION}

\section{S u m m a r y}

The aim of this article is analysis of ancient antique architectural objects exposure and the corresponding maintenance and restoration treatments. Based on international treaties, personal research and own experiences in restoration work on the archaeological sites authors describe the different ways of presenting elements of the cultural heritage such as ancient architectural monuments are. The distribution of antique objects due to the present day structure condition is provided including objects that survived in very good technical condition and objects that have not survived to this day in a form other than descriptions or images as well as other intermediate states. The exposure methods of the architectural heritage include archaeological parks and other forms of presentation, such as real and virtual reconstructions. The analysis of restoration work presents the actions specific to different objects preservation stages and different ways their future presentation. It was illustrated by examples from authors experience from archaeological sites located in Europe and Asia. The article draws attention to the need for interdisciplinary research involving not only object, which is under conservation, but also its surroundings, and similar objects with similar technology and technology applied . Such studies are necessary in order to maintain an adequate level of historical authenticity and credibility during maintenance and restoration works. The article shows the effect of the properly conducted maintenance and properly prepared exhibition of historical architectural objects on the development of the local economy and the implementation of the principles of sustainable development.

Keywords: archaeological parks, permanent ruin, international treaties on the conservation of cultural heritage, the principles of sustainable development

Przestano do redakcji: $16.03 .2015 \mathrm{r}$.

Przyjęto do druku: 22.06.2015 r.

DOI:10.7862/rb.2015.82 